\title{
Expression of growth factor ligand and receptor genes in preimplantation stage water buffalo (Bubalus bubalis) embryos and oviduct epithelial cells
}

\author{
M. Daliri, K. B. C. Appa Rao, G. Kaur, S. Garg, S. Patil and S. M. Totey* \\ Embryo Biotechnology Laboratory, National Institute of Immunology, Aruna Asaf Ali Marg, New Delhi-110067, India
}

\begin{abstract}
The temporal pattern of expression of genes for several growth factor ligands and receptors was examined in preimplantation water buffalo embryos and oviduct epithelial cells using RT-PCR. The identity of the resulting PCR products was confirmed by their expected size, restriction analysis, Southern blot hybridization and nucleotide sequence analysis. Preimplantation stage embryos from the one-cell to the blastocyst stage were derived after maturation, fertilization and culture of oocytes in vitro. Expression of members of the insulin-like growth factor (IGF) family was observed predominantly in preimplantation stage embryos and oviduct epithelial cells. Similarly, transcripts encoding insulin and IGF-I receptors were detected at each stage of embryonic development. The mRNA transcript of the IGF-I receptor was not detected in oviduct epithelial cells, but a prominent band corresponding to the insulin receptor was observed. Insulin and IGF-II mRNA were expressed as maternal transcripts that were not detected at the two- to four-cell stage but were present as zygotic transcripts at the eight-cell stage. Transcripts encoding IGF-I were detected in oviduct epithelial cells, but were not observed in any of the preimplantation stage embryos. Transforming growth factor (TGF) $\alpha$ and $\beta$ and epidermal growth factor mRNA transcripts were not detected in any of the preimplantation stage embryos. These results indicate that IGF-I acts via a paracrine mechanism to promote growth and development of preimplantation water buffalo embryos. Similarly, IGF-II appears to act through a heterologous autocrine mechanism via the IGF-I or the insulin receptor. Furthermore, the presence of TGF- $\alpha$ in oviduct epithelial cells indicates that it may have a critical role during development.
\end{abstract}

\section{Introduction}

Successful methods for producing large numbers of water buffalo embryos from abattoir-derived ovaries are well documented (Totey et al., 1992, 1993a,b, 1996a; Madan et al., 1994). However, development of specific culture regimens that are capable of supporting in vitro maturation (IVM), in vitro fertilization (IVF), and subsequent development of water buffalo zygotes to the blastocyst stage is required to produce good quality embryos.

The small number of inner cell mass (ICM) cells in IVFderived blastocysts is indicative of reduced viability, and may result in lower pregnancy rates in water buffalo (Totey et al., 1996a). However, addition of IGF-I during in vitro culture of embryos significantly increased the number of trophectoderm and ICM cells (Narula et al., 1996). IGF-I also improved bovine embryonic development in vitro (Kaye et

${ }^{*}$ Correspondence.

Revised manuscript received 3 March 1999. al., 1992; Palma et al., 1997). Insulin improved the development of preimplantation embryos in mice (Gardner and Kaye, 1991), rats (Hertogh et al., 1991), pigs (Lewis et al., 1992), cattle (Matsui et al., 1995) and water buffalo (Totey et al., 1996b). Larson et al. (1992) reported that addition of basic fibroblast growth factor and transforming growth factor $\beta$ (TGF- $\beta$ ) at physiological concentrations to the culture medium improved the development of bovine in vitro matured and fertilized zygotes beyond the 16-cell stage and up to the blastocyst stage.

Growth factors have a regulatory role in ovarian function (Adashi et al., 1985). Pawshe et al. (1998) reported that IGF-I induced proliferation of granulosa cells and maturation of oocytes in water buffalo. There was a significant increase in cleavage rate and blastocyst development when the oocytes were matured in the presence of IGF-I (Pawshe et al., 1998). This implies that IGFs have a key role in preimplantation development in mammals (Larson et al., 1992).

A number of growth factors and their cognate receptors are expressed by embryos, for example IGF-I, IGF-II, 
epidermal growth factor (EGF), TGF- $\beta$, TGF- $\alpha$ and insulin (Schultz and Heyner, 1993a). The growth factor ligand and receptor genes show differential expression before and after the onset of activation of the embryonic genome. However, the types of growth factor expressed vary in the different stages of development of the preimplantation embryo. Expression of a number of growth factor ligand and receptor genes has been demonstrated in preimplantation stage embryos in mice (Rappolee et al., 1989; Telford et al., 1990a), cattle (Schultz et al., 1992; Watson et al., 1992), rats (Zhang et al., 1994) and humans (Lighten et al., 1997). Various growth factors such as EGF, TGF- $\alpha$, TGF- $\beta$ and IGF-I have been identified in the oviducts of some mammalian species (Lei and Rao, 1992).

Since the precise role of growth factors in supporting early embryonic development in water buffalo is unclear, the aim of this study was to investigate their expression at various stages of embryonic development. Expression of mRNA transcripts encoding members of the IGF family of ligands and receptors, TGF- $\alpha$, TGF- $\beta$ and EGF has been detected in theca and cumulus and mural granulosa cells in water buffalo using RT-PCR and immunohistochemistry (S. M. Totey, unpublished). Therefore, the profile of expression of IGFs and other growth factors during embryogenesis was investigated. The prevalence of species-specific patterns of expression of these growth factors in mice (Schultz et al., 1993b), rats (Zhang et al., 1994) and cows (Watson et al., 1992) confirms their differential mode of action, which is critical for development. Therefore, in the present study, the mRNA phenotype of growth factor ligand and receptor gene expression in preimplantation buffalo embryos and oviduct epithelial cells was examined.

\section{Materials and Methods}

\section{Collection of oocytes and oviduct epithelial cells}

Collection of preimplantation water buffalo embryos at various stages and IVM and IVF of immature oocytes were carried out as described by Totey et al. (1993a). Briefly, ovaries were collected from a local abattoir and intact cumulus-oocyte complexes (COCs) that had homogeneous ooplasm and were surrounded by four to five layers of unexpanded cumulus cells were isolated by aspirating small visible follicles of $2-6 \mathrm{~mm}$ in diameter within $1 \mathrm{~h}$ after the animals were killed.

Oviducts from cyclic water buffalo were transferred from the abattoir to the laboratory on ice. Oviducts from freshly ovulated water buffalo (identified by the presence of haemorrhagic corpora lutea on the ovaries) were collected. After removal of extraneous tissue, the oviducts were rinsed thoroughly with normal saline containing $50 \mu$ g gentamycin $\mathrm{ml}^{-1}$ and blotted dry with sterile tissue paper. Epithelial cells were collected by scraping the outside of the oviduct from the infundibulum to the isthmus with a sterile glass slide. The cells were washed five to six times with TCM-199 supplemented with $10 \%$ fetal calf serum (FCS) and $50 \mu \mathrm{g}$ gentamycin ml-1 by gravity sedimentation. The pellet was resuspended and the cells were seeded in 24-well plates with
$200 \mu \mathrm{l}$ culture medium. The cells were maintained at $39^{\circ} \mathrm{C}$ under $5 \% \mathrm{CO}_{2}$ in air and $95 \%$ relative humidity. After 2 days of culture, the cells were removed and washed with TCM199 supplemented with $10 \%$ FCS and used for co-culture and RNA isolation.

\section{In vitro maturation}

COCs were washed three times in Tyrode lactate-Hepes (TL-Hepes) medium containing 0.3\% (w/v) BSA (Sigma Chemical Co., St Louis, MO). The final two washings were carried out in maturation medium consisting of Ham's F-10 medium containing 10\% FCS (Gibco BRL Life Technologies, Grand Island, NY) and supplemented with $1.25 \mathrm{mmol}$ sodium pyruvate $\mathrm{l}^{-1}, 40 \mu \mathrm{g}$ gentamycin $\mathrm{ml}^{-1}, 5 \mu \mathrm{g}$ ovine $\mathrm{LH}$ $\mathrm{ml}^{-1}, 0.5 \mu \mathrm{g}$ ovine FSH ml-1 (National Institute of Diabetes and Digestive and Kidney Disease, National Hormone and Pituitary Program, MD), and $1 \mu \mathrm{g}$ oestradiol $\mathrm{ml}^{-1}$ (Sigma). Groups of 20 COCs were randomly allocated to $100 \mu \mathrm{l}$ microdrops of maturation medium under mineral oil (Sigma) and incubated for $24 \mathrm{~h}$ at $39^{\circ} \mathrm{C}$ in a humidified atmosphere of $5 \% \mathrm{CO}_{2}$ in air.

\section{In vitro fertilization}

Motile water buffalo spermatozoa were isolated from frozen stocks using the Percoll gradient method described by Totey et al. (1993b). Matured oocytes were washed with TL-Hepes and distributed in $50 \mu \mathrm{l}$ drops of fertilization medium containing $6 \mathrm{mg}$ fatty acid free BSA ml ${ }^{-1}, 0.25 \mathrm{mmol}$ sodium pyruvate $\mathrm{l}^{-1}$ and $10 \mu \mathrm{g}$ heparin $\mathrm{ml}^{-1}$ (Sigma) under mineral oil (ten oocytes per drop) in a $60 \mathrm{~mm}$ Petri dish. A $2 \mathrm{ml}$ aliquot of sperm suspension $\left(2 \times 10^{6}\right.$ spermatozoa ml-1) was added to each drop. Oocytes and spermatozoa were coincubated for $22 \mathrm{~h}$ at $39^{\circ} \mathrm{C}$ in a humidified atmosphere of $5 \%$ $\mathrm{CO}_{2}$ in air to enable in vitro fertilization.

\section{In vitro culture}

After $22 \mathrm{~h}$ of co-incubation of spermatozoa and oocytes, the cumulus cells of the fertilized embryos were removed by repeated pipetting and the embryos were washed several times in TL-Hepes medium. The final two washings were carried out in development medium consisting of TCM-199 supplemented with $10 \%$ FCS. Twenty presumptive zygotes were randomly distributed to $100 \mu \mathrm{l}$ drops of TCM-199 under mineral oil and cocultured with oviductal cells in $5 \% \mathrm{CO}_{2}$ in air and $95 \%$ relative humidity at $39^{\circ} \mathrm{C}$. The morphology and development of the embryos were examined. Matured oocytes and embryos that were developing normally at the two-cell, four-cell, eight-cell, compact morula and mid-blastocyst stages from day 2 to day 6 of culture were selected for this study (Narula et al., 1996).

\section{Isolation of RNA}

Cumulus cells of matured unfertilized oocytes were removed by repeated pipetting. The zona pellucida was Downloaded from Bioscientifica.com at 04/26/2023 11:23:27AM 
Table 1. Sequence of growth factor primers from conserved regions of murine and human sequences and major features of the expected PCR fragments and restriction sites

\begin{tabular}{|c|c|c|c|c|}
\hline Gene & Fragment size (bp) & Restriction site & Primer sequence $\left(5^{\prime}-3^{\prime}\right)$ & Reference \\
\hline IGF-I ligand & 210 & Msp I & $\begin{array}{l}\text { 5. GGACCAGAGACCCTTTGCGGGG } \\
\text { 3. GGCTGCTTTTGTAGGCTTCAGTGG }\end{array}$ & Bell et al., 1986 \\
\hline IGF-II ligand & 256 & Sac II & $\begin{array}{l}5 \text { ' CGCCCCAGCGAGACTCTGTGC } \\
\text { 3' GCCCACGGGGTATCTGGGGAA }\end{array}$ & Dull et al., 1984 \\
\hline Insulin ligand & 300 & Sma I & $\begin{array}{l}5 . \text { GATGCGCTTCCTGCCCCTGGTGGC } \\
3 . \text { GTTGGTAGAGGGAGCAGATGTGG }\end{array}$ & Bell et al., 1980 \\
\hline Insulin receptor & 324 & Hinc II & $\begin{array}{l}5^{\prime} \text { GTCACTGACCTCATGCGCATGTGCTGG } \\
3^{\prime} \text { CCGCCCGTTTTTCTTGCCTCCGTTCAT }\end{array}$ & Ullrich et al., 1985 \\
\hline IGF-I receptor & 354 & Ban II & $\begin{array}{l}5^{\prime} \text { ATGCTGTTTGAACTGATGCGCATGTGCTGG } \\
3 . \text { CCGCTCGTTCTTGCGGCCCCCGTTCAT }\end{array}$ & Ullrich et al., 1986 \\
\hline IGF-II receptor & 186 & Taq I & $\begin{array}{l}5 \text { TGTACACTCTTCTTCTCCTGGCA } \\
3 \text { AGAGATGTTGATGTAGAAGACAGG }\end{array}$ & $\begin{array}{l}\text { Morgan et al., 1987; } \\
\text { Telford et al., 1990b }\end{array}$ \\
\hline TGF- $\beta 2$ & 273 & Sph I & $\begin{array}{l}5 \text { AGAAATGTGCAGGATAATTGCTGC } \\
\text { 3. TTCGATCTTGGGCGTATTTCCAAT }\end{array}$ & Miller et al., 1989 \\
\hline TGF- $\alpha$ & 239 & $\operatorname{Sph} \mathbf{I}$ & $\begin{array}{l}5 \text { ACCTGCAGGTTTTTGGTGCAG } \\
3 \text { GCAGACGAGGGCACGGCACCA }\end{array}$ & Derynck et al., 1986 \\
\hline EGF & 247 & Rsa I & $\begin{array}{l}5 . \text { CCAGTTCAGTAGAAACTGGG } \\
\text { 3. TGGTTTCTAATGATTTTCTCC }\end{array}$ & Gray et al., 1983 \\
\hline$\beta$ actin & 243 & $\mathrm{Bgl} \mathrm{II}$ & $\begin{array}{l}\text { 5. CGTGGGCCGCCCTAGGCACCA } \\
\text { 3. TTGGCCTTAGGGTTCAGGGGGG }\end{array}$ & Tokunaga et al., 1986 \\
\hline
\end{tabular}

IGF, insulin-like growth factor; TGF, transforming growth factor; EGF, epidermal growth factor.

$\beta$ actin was included as an internal control.

removed by treating the oocytes and embryos with acidTyrode's medium. Zona free oocytes and embryos were collected according to their stage of development. Oviduct epithelial cells were collected after 2 days of culture. A buffalo lung-derived cell line (Bu-IMR-31) and a rat liverderived cell line (BRL-3A) were cultured simultaneously in McCoy's medium and minimum essential medium (Gibco), respectively, supplemented with $10 \%$ FCS and antibiotics and used as controls. Before extraction of RNA, all the cells, including the oocytes and embryos, were washed with collection medium consisting of bicarbonate-free minimal essential medium (Earle's salt) containing $100 \mu \mathrm{g}$ sodium pyruvate $\mathrm{ml}^{-1}, 10 \mu \mathrm{g}$ gentamycin $\mathrm{ml}^{-1}, 3 \mathrm{mg}$ polyvinyl pyrolidone (PVP) $\mathrm{ml}^{-1}$, and $25 \mathrm{mmol}$ Hepes $\mathrm{l}^{-1}, \mathrm{pH} 7.2$, and transferred in a minimal volume of medium to a chilled $0.6 \mathrm{ml}$ microfuge tube on ice. Total RNA was isolated from 300 matured unfertilized oocytes, 200 embryos at each of the two-cell, four-cell, eight-cell and morula stages, 150 blastocysts, approximately 10000 oviduct epithelial cells, $1 \times 10^{6}$ BRL-3A cells, and $1 \times 10^{6}$ Bu-IMR-31 cells as described by Doherty et al. (1994). Each experiment was repeated three times using the same number of oocytes, embryos and cells to enable comparative analysis.

\section{$R T-P C R$ procedures}

Total RNA from BRL-3A and Bu-IMR-31 cells $(3 \mu \mathrm{g})$ and from embryos at the different stages of development $(1 \mu \mathrm{g})$ was used for reverse transcription. The reaction was performed in a total volume of $30 \mathrm{ml}$ consisting of $10 \mu \mathrm{l}$ total RNA, $6 \mu \mathrm{l}$ of

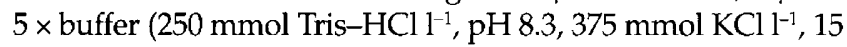
mmol $\left.\mathrm{MgCl}_{2} \mathrm{l}^{-1}\right), 1.5 \mathrm{ml}^{2}$-deoxyribonucleoside triphosphates
(dNTPs) ( 1 mmol l-1 each of dATP, dGTP, dCTP, dTTP), $3 \mu \mathrm{l}$ of $0.1 \mathrm{~mol}$ dithiothretiol (DTT) $\mathrm{l}^{-1}, 1 \mu \mathrm{l}(0.5 \mu \mathrm{g})$ oligo (2'deoxyribosylthymidine) 12-18 (Gibco) and $0.5 \mu \mathrm{l}$ (14 U) RNasin (Promega). The volume was made up to $30 \mu \mathrm{l}$ with distilled water. The reaction was carried out in $0.6 \mathrm{ml}$ Gen Amp thin walled tubes (Perkin Elmer Cetus, Norwalk, CT). The tubes were incubated at $37^{\circ} \mathrm{C}$ for $2 \mathrm{~min}$ in a thermocycler (Perkin Elmer Cetus) before addition of $1 \mu \mathrm{l}(200 \mathrm{U})$ Superscript II reverse transcriptase enzyme (Gibco). The tubes were returned to the thermocycler and reverse transcription was carried out at $42^{\circ} \mathrm{C}$ for $1 \mathrm{~h}$. The tubes were heated to $99^{\circ} \mathrm{C}$ for $5 \mathrm{~min}$ to inactivate the enzyme, and were then placed immediately on ice.

Oligonucleotide primer pairs were chemically synthesized at Bio-synthesis, Inc., Louisville, TX, and Rama Biotechnologies Pvt Ltd, Hyderabad, India. The sequences, expected size of PCR fragments and restriction sites are shown (Table 1). A primer pair for mouse $\beta$ actin cDNA was included as an internal control. All the growth factor primers included an intron, so that product derived from genomic DNA contamination would be larger than the product of the reverse transcribed mRNA.

PCR was carried out in a total volume of $25 \mu \mathrm{l}$ in a Gen Amp thin walled tube. Each reaction mixture contained 2-3 $\mu \mathrm{l}$ cDNA solution, $2.5 \mu \mathrm{l}$ of $10 \times$ buffer $(200 \mathrm{mmol}$ Tris- $\mathrm{HCl}$ $\left.\mathrm{l}^{-1}, \mathrm{pH} 8.4,500 \mathrm{mmol} \mathrm{KCl} \mathrm{l}^{-1}\right), 0.9 \mu \mathrm{l}$ of $50 \mathrm{mmol} \mathrm{MgCl}_{2} \mathrm{l}^{-1}$, $0.5 \mu \mathrm{ldNTPs}$ ( $10 \mathrm{mmol} \mathrm{l}^{-1}$ each of dATP, dGTP, dCTP, dTTP), $1 \mathrm{ml}$ each of appropriate $3^{\prime}$ and $5^{\prime}$ primers $(20 \mathrm{pmol})$ and $2.5 \mathrm{U}$ Taq DNA polymerase (Gibco). The volume was made up to $25 \mu l$ with distilled water and the mixture was overlaid with mineral oil. After an initial denaturation at $94^{\circ} \mathrm{C}$ for $1 \mathrm{~min}$, the thermocycler was programmed for 40 cycles. Each cycle consisted of $94^{\circ} \mathrm{C}$ for $30 \mathrm{~s}, 60^{\circ} \mathrm{C}$ for $45 \mathrm{~s}$ (annealing), and $72^{\circ} \mathrm{C}$ 
for $45 \mathrm{~s}$ (extension). The final cycle included an additional thermal delay for $5 \mathrm{~min}$ at $72^{\circ} \mathrm{C}$ for complete extension. The tubes were chilled on ice and centrifuged at $400 \mathrm{~g}$ for $30 \mathrm{~s}$. After PCR amplification, 3.3 U RNase H (Gibco) was added to the sample and the tubes were incubated at $37^{\circ} \mathrm{C}$ for $20 \mathrm{~min}$. After addition of $3 \mu \mathrm{l}$ of $6 \times$ loading buffer $(0.25 \%$ $(\mathrm{v} / \mathrm{v})$ bromophenol blue in $30 \%(\mathrm{v} / \mathrm{v})$ glycerol), $15 \mu \mathrm{l}$ of each sample was subjected to electrophoresis on a $1.8 \%(\mathrm{w} / \mathrm{v})$ agarose gel, stained with ethidium bromide and photographed under UV light.

\section{Verification of $R T-P C R$ products}

The authenticity of the PCR products was analysed by digestion with a specific restriction endonuclease or by Southern blot analysis after the PCR products were transferred to a genescreen plus membrane (NEN Research Product, Boston, MA) as described by Telford et al. (1990a), and subsequently by cloning and sequencing of the PCR product. PCR amplified products were resolved on $1.8 \%$ $(\mathrm{w} / \mathrm{v})$ agarose gels. The distinct fragments were eluted from the gel and cloned directly into the pMos Blue T-vector according to the manufacturer's instructions (Amersham International, Amersham). The plasmid DNA was isolated from the positive clones using the alkaline lysis method and purified by precipitation with polyethylene glycol (Sambrook et al., 1989). The double-stranded DNA was sequenced by Sanger's dideoxynucleotide chain termination procedure using a sequenase version 2.0 DNA sequencing kit (USB Corp., Cleveland, $\mathrm{OH}$ ), universal primers and growth factor specific oligonucleotide primers. The sequences obtained were compared with known sequences from other species and were analysed using GCG and DNASIS software packages.

\section{Results}

Expression of various growth factor ligand (insulin, IGF-I, IGF-II, TGF- $\alpha$, TGF- $\beta$ and EGF) and receptor mRNA transcripts (insulin, IGF-I and IGF-II) was studied in preimplantation water buffalo embryos at various stages of development and in oviduct epithelial cells. The oligonucleotide primers used were derived from conserved regions of murine and human sequences (Table 1). Two transformed cell lines were used to test whether these primers would primarily amplify similar cDNA sequences in water buffalo: BRL-3A (derived from rat liver) and Bu-IMR31 (derived from water buffalo lung). The cell lines were included as controls to validate the performance of the PCR. The primers worked well in the buffalo-derived cell line, and amplified similar cDNA sequences as observed in the ratderived cell line, unless otherwise stated (Fig. 1 and Table 2). $\beta$ actin was included as a positive control to evaluate the quality of the isolated RNA, the extent of DNA contamination, and the PCR procedure. The primers were designed to amplify $330 \mathrm{bp}$ fragments in the event of genomic DNA contamination and $243 \mathrm{bp}$ fragments from cDNA. A single 243 bp band was obtained in all the RNA samples used in the study, indicating that there was no contamination by genomic DNA during RNA extraction. Similarly, all the growth factor primers selected from the literature (Table 1) included an intron, so that product derived from genomic DNA contamination would be larger than the product of the reverse transcribed mRNA. Final confirmation of each PCR product was carried out by sequencing.

\section{Expression of IGF-I and IGF-I receptor}

An expected $210 \mathrm{bp}$ fragment encoding IGF-I was observed in the rat-derived (Fig. 1a) and buffalo-derived cell lines (Fig. 2, lanes 1-3) and oviduct epithelial cells (Fig. 1i; Fig. 2, lanes 4-6). However, IGF-I ligand was not detected at any stage in development of the preimplantation embryos (Fig. 1c-h). In the Bu-IMR-31 cell line (Fig. 1b) and oviduct epithelial cells, IGF-I primers occasionally amplified a major $432 \mathrm{bp}$ fragment instead of the expected $210 \mathrm{bp}$ fragment, or a $610 \mathrm{bp}$ fragment was observed in addition to the expected 210 bp IGF-I fragment (Fig. 2). Restriction analysis showed that Msp I digestion of the 210 bp product yielded 149 and 61 bp subfragments in both cell lines and in oviduct epithelial cells, whereas the $432 \mathrm{bp}$ fragment yielded 244 and $188 \mathrm{bp}$ subfragments (Fig. 3a) in Bu-IMR-31 and oviduct epithelial cells. The identity of the two amplified products was verified by Southern blot hybridization with a ${ }^{32} \mathrm{P}$-labelled murine IGF-I cDNA probe. The probe hybridized strongly to both 210 and $432 \mathrm{bp}$ sequences (Fig. 3b). cDNA was freshly transcribed from poly $(\mathrm{A})+$ mRNA instead of total RNA from the BU-IMR-31 cell line and oviduct epithelial cells to characterize both fragments further. The $432 \mathrm{bp}$ fragment was not observed when poly (A)+ mRNA was used, whereas the 210 and $610 \mathrm{bp}$ fragments were amplified. All the PCR fragments from the Bu-IMR-31 cell line and oviduct epithelial cells were subjected to sequence analysis. The 210 bp fragment obtained from the Bu-IMR-31 cell line consisted of 207 nucleotides (Genbank accession no. Y 10691) and from the oviduct epithelial cells consisted of 210 nucleotides (Genbank accession no. Y 16248); both were IGF-IA. Deletion of three bases in the fragment from the Bu-IMR-31 cell line at positions 40, 41 and 47 (each a thymidine) was not detected in the oviduct epithelial cells (Fig. 4). Both nucleotide sequences encode 70 amino acids and contain insulin family signatures at positions $46-60$. The sequences showed up to $98 \%$ homology to mouse, $86 \%$ homology to human, $83.3 \%$ homology to ovine and $84.2 \%$ homology to marmoset IGF-I ligand sequences. Partial sequence analysis of the $432 \mathrm{bp}$ PCR fragment revealed it to be $99 \%$ homologous to rat 185 rRNA (Fig. 5). The sequence has been deposited with Genbank (accession no. Y 12516). The $610 \mathrm{bp}$ fragment did not show homology to any of the databases in Genbank.

Transcripts encoding the IGF-I receptor were detected in all developmental stages of the preimplantation embryos (Fig. 1c-h). The $357 \mathrm{bp}$ RT-PCR product for the IGF-I receptor was not detected in oviduct epithelial cells, but a prominent amplified product of $327 \mathrm{bp}$ corresponding to the size of the insulin receptor was detected (Fig. 1i). Restriction digestion with Ban II enzyme resulted in cleavage of the 357 Downloaded from Bioscientifica.com at 04/26/2023 11:23:27AM 

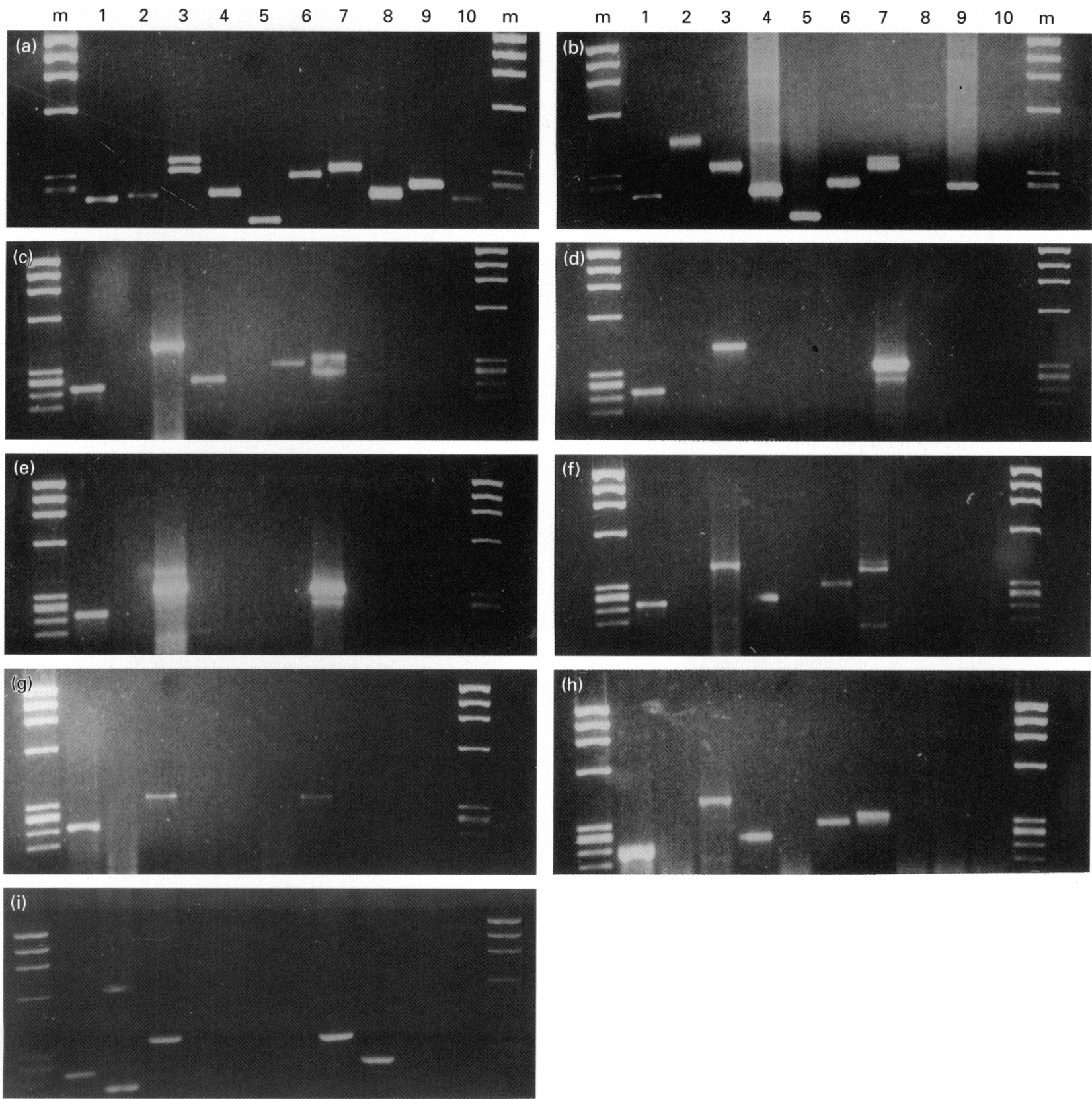

Fig. 1. Detection of mR.NA transcripts by RT-I'CR. (a) A rat liver-derived cell line (BRL-3A): lane 1, 210 bp insulin-like growth factor I (IGF-I) ligand; lane 2, 243 bp \& actin fragment; lane 3, ICF-I receptor; lane 4, IGF-II ligand; lane 5, ICiF-II receptor; lane 6, insulin; lane 7 , insulin receptor; lane 8, transforming growth factor a (TCF-(e); lane 9, TGF-pi2; lane 10, epidermal growth factor (ECF). (b) A water buffalo lung-derived cell line (Bu-IMR-31). (c-h) Preimplantation water buffalo embryos: (c) oocyte, (d) two-cell, (e) four-cell, (f) eightcell, (g) morula, (h) blastocyst. (i) Water buffalo oviduct epithelial cells. (b-i) Lane 1, single 243 bp fragment for p actin expression, indicating that there is no contamination by genomic DNA; lane 2, IGF-I ligand; lane 3, IGF-I receptor; lane 4, KGF-II ligand; lane 5, IC iF-II recepter; lane 6, insulin ligand; lane 7 , insulin receptor; lane 8, TCF-e; lane 9, TGF- 32 ; lane 10, EGF. The PCR products were resolved on $1.8^{\prime \prime},(w / \mathrm{r})$ agrarose gels. m, molecular size marker (OX 174 RF D.VA digested with Hae III restriction (enzyme).

bp product into three fragments of 176,101 and $80 \mathrm{bp}$ (Fig. $3 \mathrm{~d})$, but did not cleave the 327 bp band, which was identified as a crossreactive product of the insulin receptor. Similarly, in the rat-derived cell line and in four-cell embryos, in addition to the expected $357 \mathrm{bp}$ fragment of the ICF-I receptor, a crossreactive 327 bp fragment of the insulin receptor was observed (Fig. 1a,c). Sequence analysis revealed the authenticity of both PCR fragments. The 357 bp fragment amplified by IGF-I receptor primers was identified as the IGF-I receptor (Genbank accession no. Y 12700), whereas the crossreactive product of the $327 \mathrm{bp}$ fragment was identified as the insulin receptor (Genbank accession no. Y 14017). 
Table 2. Growth factor ligand and receptor mRNA transcripts expressed in preimplantation stage water buffalo embryos and oviduct epithelial cells

\begin{tabular}{|c|c|c|c|c|c|c|c|c|c|}
\hline \multirow[b]{2}{*}{ Growth factor } & \multicolumn{6}{|c|}{ Stage of embryo development } & \multirow[b]{2}{*}{ Oviductal cells } & \multicolumn{2}{|c|}{ Controls } \\
\hline & Oocyte & Two-cell & Four-cell & Eight-cell & Morula & Blastocyst & & Bu-IMR-31 & BRL-3A \\
\hline$\beta$ actin & + & + & + & + & + & + & + & + & + \\
\hline IGF-I & - & - & - & - & - & - & + & + & + \\
\hline IGF-I receptor & + & + & + & + & - & + & - & + & + \\
\hline IGF-II & + & - & - & + & - & + & - & + & + \\
\hline IGF-II receptor & - & - & - & - & - & - & - & + & + \\
\hline Insulin & + & - & - & + & - & + & - & + & + \\
\hline Insulin receptor & + & + & + & + & + & + & + & + & + \\
\hline $\mathrm{TGF}-\alpha$ & - & - & - & - & - & - & + & + & + \\
\hline $\mathrm{TGF}-\beta$ & - & - & - & - & - & - & - & + & + \\
\hline $\mathrm{EGF}$ & - & - & - & - & - & - & - & - & + \\
\hline
\end{tabular}

IGF, insulin-like growth factor; TGF, transforming growth factor; EGF, epidermal growth factor.

Bu-IMR-31, buffalo lung-derived cell line; BRL-3A, rat liver-derived cell line.

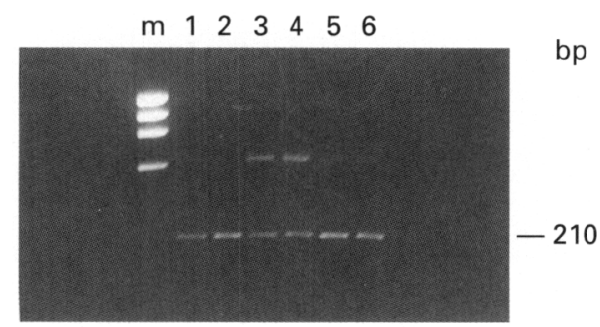

Fig. 2. Detection of $210 \mathrm{bp}$ fragment of insulin-like growth factor I (IGF-I) mRNA transcripts in water buffalo lung-derived cell line (BuIMR-3) (lanes 1-3) and water buffalo oviduct epithelial cells (lanes 4-6). m, molecular size marker ( $\varnothing \times 174$ RF DNA digested with Hae III restriction enzyme).

\section{Expression of insulin and insulin receptors}

A single 300 bp RT-PCR product for the insulin ligand was detected in oocytes (Fig. 1c), but was not detected in embryos at the two-cell (Fig. 1d) and the four-cell (Fig. 1e) stages. The transcript was apparent in embryos at the eight-cell (Fig. 1f) and the blastocyst stages (Fig. 1h), but was not detected in morulae (Fig. 1g) and oviduct epithelial cells (Fig. 1i).

Analysis of the pattern of transcription of the insulin receptor by $R T-P C R$ showed the presence of a single expected $327 \mathrm{bp}$ amplified product in oocytes (Fig. 1c), all embryonic stages (Fig. 1d-h) and oviduct epithelial cells (Fig. 1i). In addition, a $280 \mathrm{bp}$ PCR fragment was present in these samples. Restriction digestion using the Hinc II enzyme confirmed the presence of a single restriction site in the 327 bp insulin receptor in the rat-derived cell line, but not in the water buffalo-derived cell line. Further restriction analysis of the 327 and $280 \mathrm{bp}$ fragments of the water buffalo-derived insulin receptor using a panel of restriction enzymes revealed the presence of Msp I sites. The $327 \mathrm{bp}$ buffalo cDNA sequence (Genbank accession no. Y 14017) shares $95 \%$ homology with the human insulin receptor gene sequence, whereas the co-amplified product of $280 \mathrm{bp}$ (Genbank accession no. Y 14610) did not show significant homology to any of the databases in Genbank.

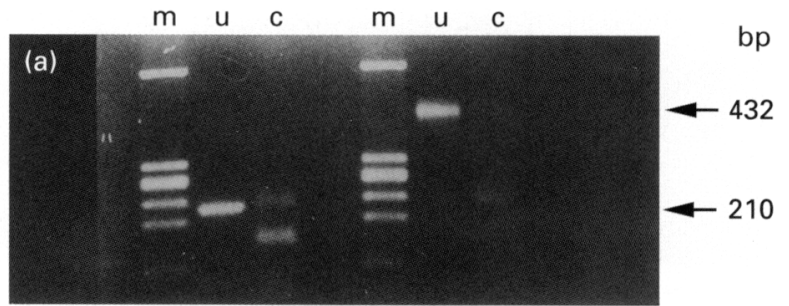

(b)

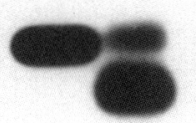

Fig. 3. Verification of RT-PCR fragment identity by restriction enzyme analysis. (a) Uncut (u) and MspI cut (c) 210 and 432 bp PCR products of insulin-like growth factor I (IGF-I) were resolved on $1.8 \%(\mathrm{w} / \mathrm{v})$ agarose gel. $\mathrm{m}$, molecular size marker ( $\varnothing \mathrm{X} 174 \mathrm{RF}$ DNA digested with Hae III restriction enzyme). (b) Southern hybridization of IGF-I ligand PCR product cut with Msp I. Hybridization was carried out with ${ }^{32} \mathrm{P}$-labelled rat IGF-I ligand cDNA probe.

\section{Expression of IGF-II and IGF-II receptor}

A single IGF-II-derived fragment of $256 \mathrm{bp}$ was detected in oocytes (Fig. 1c) and embryos at the eight-cell and blastocyst stages (Fig. 1f,h), but not in morulae (Fig. 1g) and oviduct epithelial cells (Fig. 1i). Similar to insulin, the transcript for the IGF-II ligand was not detected in embryos at the two- or four-cell stages (Fig. 1d,e). Restriction digestion with the appropriate enzyme, Sac II, yielded fragments of expected size (189 and $67 \mathrm{bp}$ ).

The transcripts for the IGF-II receptor were not observed in the oviduct epithelial cells, oocytes and or any of the embryonic stages (Fig. 1c-i), although an expected $186 \mathrm{bp}$ IGF-II receptor product was identified in both the control cell lines (Fig. 1a,b). The authenticity of the $186 \mathrm{bp}$ fragment was verified by Taq I digestion which resulted in fragments of 105 and $81 \mathrm{bp}$. 
(a)

ggaccagaga cccttgcgg

ggctgagctg gtggatcct- -tcagt-cgt

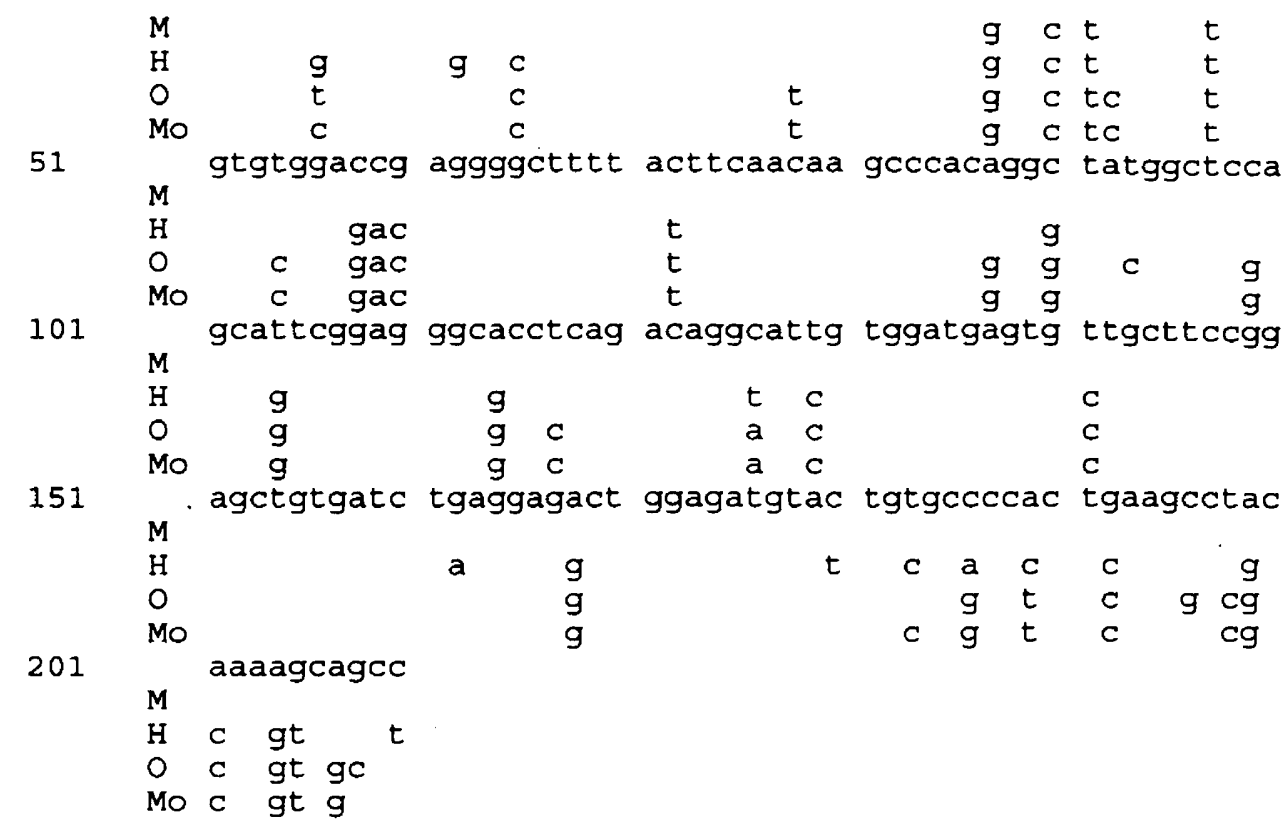

(b)

\section{GPETLCGAEL VDPSV-VCGP RGFYFNKPTG YGSSIRRAPQ TGIVDECCFR \\ 51 SCDLRRLEMY CAPLKPTKAA}

Fig. 4. (a) Nucleotide and (b) predicted amino acid sequences of insulin-like growth factor I (IGF-I) ligand amplicon of $207 \mathrm{bp}$ (Genbank accession no. Y 10691). The percentage homology with other species is shown. $\mathrm{M}$, murine; $\mathrm{H}$, human; $\mathrm{O}$, ovine; $\mathrm{Mo}$, marmoset.

\section{Expression of TGF and EGF}

Although expected 239, 273 and 247 bp TGF- $\alpha$, TGF- $\beta 2$ and EGF products were detected in the positive control cell line (BRL-3A) (Fig. 1a), only the TGF- $\alpha$ and TGF- $\beta 2$ transcripts were present in the Bu-IMR-31 cell line (Fig. 1b). The RT-PCR analysis showed an absence of these growth factors in oocytes (Fig. 1c) and embryos (Fig. 1d-h). However, the $239 \mathrm{bp}$ amplified product, corresponding to the transcript for TGF- $\alpha$, was detected in oviduct epithelial cells (Fig. 1i). The authenticity of the $239 \mathrm{bp}$ fragment of TGF$\alpha$ was verified with restriction analysis using Sph I.

\section{Discussion}

The expression of various growth factors and their receptors in preimplantation stage water buffalo embryos and oviduct epithelial cells in primary culture was characterized using RT-PCR. The oligonucleotide primers used were designed from known mouse or human cDNA sequences. The sequence of the exons encoding the mature insulin protein and IGF peptides are highly conserved among vertebrate species (Le Roith et al., 1993). Initially, the heterologous primers were investigated using a cell line derived from water buffalo lung (Bu-IMR-31) and also a rat liver cell line (BRL-3A) to determine whether they would amplify growth factor ligand and receptor sequences in water buffalo. It was confirmed that the human and mouse primer sequences of various growth factors recognized similar heterologous growth factor gene sequences in water buffalo, except possibly EGF. Although a fixed amount of RNA was used for the experimental samples, which was a smaller amount than in the positive control, it was enough to confirm the presence or absence of the transcript in the specific types of cell tested. Thus, these data provide qualitative evidence on the presence or absence of growth factor mRNA transcripts.

The mRNA transcripts encoding the IGF-I ligand were not detected in any of the preimplantation stage embryos, although the ligand was detected in oviduct epithelial cells. This indicates that IGF-I is unlikely to act via an autocrine mechanism during preimplantation embryo development in water buffalo. IGF-I mRNA is translated in oviductal cells and its action appears to be regulated by four IGF binding proteins (S. M. Totey, unpublished). Although in vitro development of embryos from many mammalian species can be maintained independently of the maternal environment, co-culturing with oviductal cells significantly increases the rate of development of blastocysts (Totey et al., 1992). The expression of IGF-I in oviduct epithelial cells and the presence of the IGF-I receptor on preimplantation stage embryos indicates a paracrine mode of action in water buffalo. These results are in contrast to other reports in cattle, 

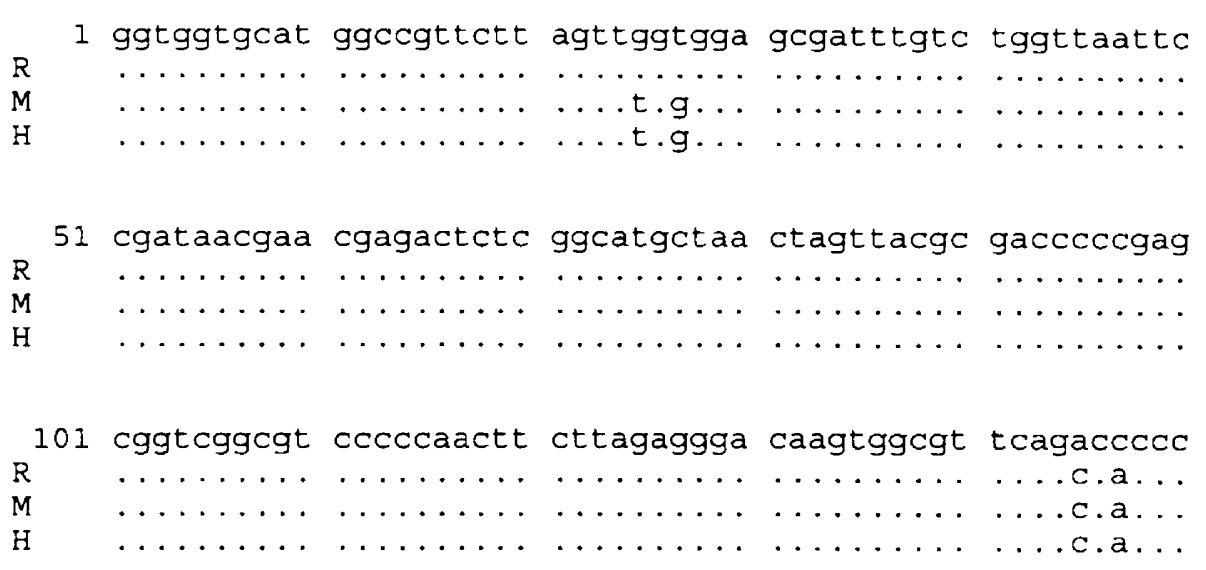

151 ccgagattga gcaataaagg ctgtgNNNNN NNNNNNNNNN NNNNNNNNNN

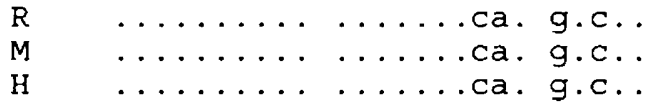

201 NNNNNNNNNN NNNNNNNNINN NNNNNNNNINN NNNNNNNNNN NNNNNNNNNN $\mathrm{R}$ M

$\mathrm{H}$
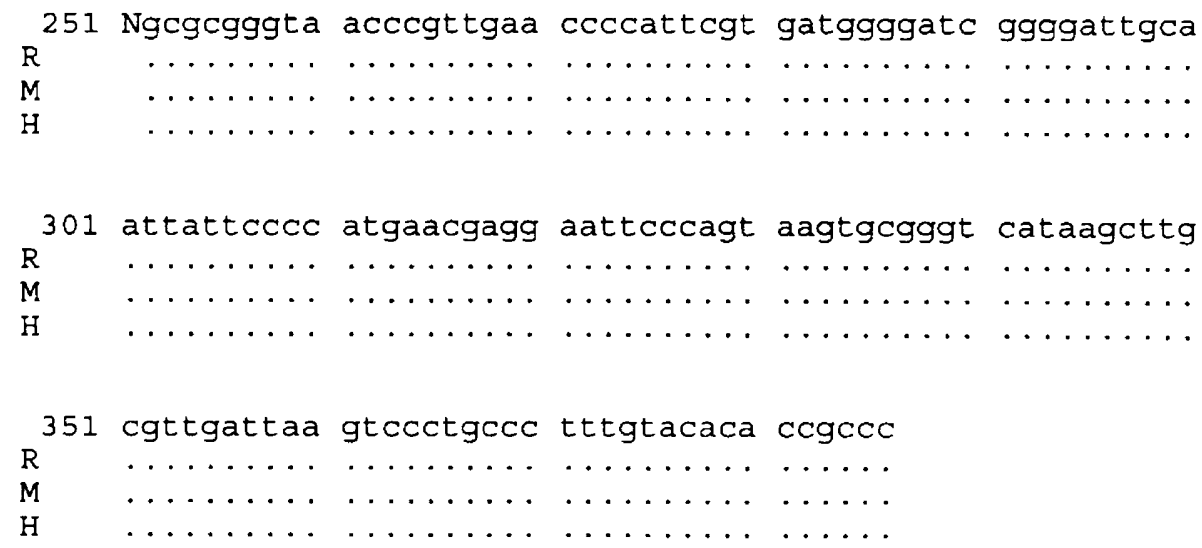

Fig. 5. Nucleotide sequence of water buffalo $18 \mathrm{~S}$ rRNA (390 bp) co-amplified using insulin-like growth factor I (IGF-I) primers (Genbank accession no. Y 12516). The percentage homology with other species is shown. $\mathrm{R}$, rat; $M$, mouse; $H$, human.

in which transcripts for IGF-I were not detected in oviductal cells (Watson et al., 1992; Viuff et al., 1995). The IGF-I transcript was present in cattle and mouse embryos at all stages (Watson et al., 1992; Doherty et al., 1994). However, in rats and humans, the IGF-I transcript was not detected in preimplantation embryos, but was found in the oviduct and uterus (Zhang et al., 1994; Lighten et al., 1997).

The oligonucleotide primers of IGF-I resulted in two distinct amplified products of 210 and $432 \mathrm{bp}$. The verification of these amplified products revealed that the 432 bp product was detected only when a preparation of total RNA was used as the template for the RT-PCR and was not apparent when poly(A)+ mRNA was used. The $432 \mathrm{bp}$ fragment was shown to be $99 \%$ homologous to $18 \mathrm{~S}$ ribosomal RNA. This is the first report to indicate that oligonucleotide primers of IGF-I can crossreact with $18 \mathrm{~S}$ ribosomal RNA in water buffalo during PCR. Viuff et al. (1995) demonstrated that an IGF-I cDNA probe crosshybridizes with the $28 / 18 \mathrm{~S}$ ribosomal band obtained from total RNA. There is evidence that base pairings between some eukaryotic mRNAs, such as human IGF-I and the $3^{\prime}$ end of $18 \mathrm{~S}$ rRNA, might have a role in the initiation of eukaryotic translation (Jansen et al., 1983). In the present study, the abundance of the transcript and the appearance of the expected $210 \mathrm{bp}$ amplified product often varied between different batches of RNA. This may be due to the short halfDownloaded from Bioscientifica.com at 04/26/2023 11:23:27AM 
life of the IGF-I transcript. Hepler et al. (1990) reported that the functional significance of different IGF-I mRNA size classes is related to differences in their stability.

IGF-II and insulin were detected as a maternal transcript in unfertilized eggs, but they were not apparent at the two- to four-cell stage when most maternal mRNA in the mammalian embryo is destroyed (Telford et al., 1990a). However, IGF-II and insulin were resynthesized in the zygote at the eight-cell stage as zygotic transcripts. In contrast, transcripts for insulin were not detected in preimplantation stage embryos of murine, bovine or human origin (Schultz et al., 1992; Lighten et al., 1997). The expression of insulin in mouse and human embryos commences after implantation (Rappolee et al., 1992; Lighten et al., 1997). Although there were strong signals of transcripts encoding the IGF-I receptor, insulin and IGF-II at the eightcell and the blastocyst stages, they were not visualized by ethidium bromide staining in morula stage embryos. An increase in the number of PCR cycles did not increase the ability to detect the transcript in morula stage embryos. However, mRNA transcripts for the insulin receptor were detected in water buffalo embryos at all stages of development, including morulae, as well as in oviduct epithelial cells. The presence of insulin receptors within the embryo and oviductal cells indicates that embryonic development is supported by both autocrine and paracrine modes of action of insulin. The degradation of the transcript at the two- to four-cell stage in buffalo may indicate that embryogenesis is affected by the expression of zygotic growth factor genes and that the maternal-zygotic transition takes place at the two- to four-cell stage. However, this hypothesis requires further confirmation, since IGF-I receptor, insulin and IGF-II transcripts were not visualized by ethidium bromide staining in morula stage embryos, it is also possible that the relevant zygotic genes are not expressed until the blastocyst stage and, if so, the transcripts at the eight-cell stage may not be from the zygotic genome. There is evidence that IGF-II exerts its growth promoting effect through IGF-I receptors or insulin receptors rather than through the IGF-II receptor (Czech and Ullrich, 1988; MacDonald et al., 1988; Rappolee et al., 1992). In the present study, IGF-II receptors were not detected in either preimplantation stage embryos or in oviductal cells, thus it is postulated that in water buffalo IGF-II may also act through IGF-I or insulin receptors.

There is considerable homology between IGF-I and insulin receptors (Ebina et al., 1985; Ullrich et al., 1985, 1986; Telford ef al., 1990b) and this may increase the tendency for primer pairs to crossreact with each other. Indeed, the primers used in the PCR of the IGF-I receptor amplified a 327 bp crossreactive sequence of the insulin receptor and an additional $280 \mathrm{bp}$ fragment. Differential restriction digestion using Ban II, which is appropriate for IGF-I receptor, and Hinc II, which is specific for the insulin receptor, did not cleave any of the crossreactive PCR products of the insulin receptor. This indicates that the Hinc II site may be absent from the water buffalo insulin receptor fragment. The $280 \mathrm{bp}$ fragment amplified in addition to the insulin receptor and the $610 \mathrm{bp}$ fragment amplified in addition to IGF-I did not show significant homology to any of the database sequences in Genbank and are worthy of further investigation.
Although the TGF- $\alpha$ transcript was detected in oviduct epithelial cells, it was not observed at any stage of development of the preimplantation embryo. The role of TGF- $\alpha$ in the water buffalo embryo remains to be elucidated. Addition of exogenous TGF- $\alpha$ to in vitro culture medium did not show any beneficial effect on embryonic development (S. M. Totey, unpublished). Other growth factor transcripts such as TGF- $\beta 2$ and EGF were also not detected in preimplantation buffalo embryos and oviduct epithelial cells.

Although many of the growth factors and their receptors are expressed in murine, bovine and water buffalo embryos, the embryonic stages at which transcripts can be detected differ among these species. This indicates that the pattern of growth factor expression and mode of action at different stages of embryonic development is species specific. The addition of insulin and IGF enhances embryonic development in water buffalo in vitro (Totey et al., 1996b). Similarly, the number of trophectoderm and ICM cells is significantly increased in blastocysts cultured in the presence of IGF-I (Narula et al., 1996). Gardner and Kaye (1991) reported similar results in mice.

In conclusion, the results of the present study indicate that growth factors such as insulin, IGF-I and IGF-II and their receptors are selectively expressed at various stages of embryonic development. This indicates that they are important in the development of preimplantation stage water buffalo embryos, but further confirmation is required. In addition, IGF-I is produced by oviduct epithelial cells and may act via a paracrine mechanism within the water buffalo oviduct to provide an optimal environment for embryonic development.

This work was supported by a grant from the Department of Biotechnology, Government of India. The authors gratefully acknowledge the generous gifts of oLH and oFSH provided by A. F. Parlow, National Institute of Diabetes and Digestive and Kidney Diseases, National Hormone and Pituitary Program, MD, USA, and the murine IGF-I cDNA probe provided by G. A. Schultz, Department of Medical Biochemistry, University of Calgary Health Sciences Center, Calgary, Alberta, Canada. Technical assistance provided by Ramesh Kumar and Radhey Shyam is also acknowledged.

\section{References}

Adashi EY, Resnick CE, D'Ercole J, Svoboda ME and Van Wyk JJ (1985) Insulin-like growth factors as intraovarian regulators of granulosa cells Endocrinological Reviews 6 400-420

Bell GI, Pietet RL, Rutter WJ, Cordell B, Tischer E and Goodman HM (1980) Sequence of the human insulin gene Nature 284 26-32

Bell GI, Stempien MM, Fong NM and Rall LB (1986) Sequences of liver cDNA encoding two different mouse insulin-like grow th factor I precursors Nucleic Acids Research 14 7873-7882

Czech MP and Ullrich A (1988) A single receptor binds both insulin-like growth factor II and mannose- $\beta$-phosphate Science 239 1134-1137

Derynck R, Jarett JA, Chen EY and Goeddel DV (1986) The murine transforming growth factor- $\beta$ precursor Journal of Biological Chemistry $\mathbf{2 6 1}$ $4377-4379$

Doherty AS, Temeles GL and Schultz RM (1994) Temporal pattern of IGF-I expression during mouse preimplantation embryogenesis Molecular Reproduction and Development 37 21-26

Dull TJ, Gray A, Hayflick JS and Ullrich A (1984) Insulin-like growth factor II 
precursor gene organization in relation to insulin gene family Nature $\mathbf{3 1 0}$ $777-781$

Ebina Y, Ellis L, Jarnigin K et al. (1985) The human insulin-receptor cDNA: the structural basis for hormone-activated transmembrane signalling Cell 40 $747-758$

Gardner HG and Kaye PL (1991) Insulin increases cell numbers and morphological development in mouse pre-implantation embryos in vitro. Reproduction Fertility and Development 3 79-91

Gray A, Dull TJ and Ullrich A (1983) Nucleotide sequence of epidermal growth factor cDNA predicts a 128000 molecular weight protein precursor Nature 303 722-725

Hepler JE, Van Wyk JJ and Lund PK (1990) Different half-lives of insulin-like growth factor I mRNAs that differ in length of 3 ' untranslated sequence Endocrinology 127 1550-1552

Hertogh RD, Vanderheyden I, Pampfer S, Robin D, Dufrasne E and Delcourt J (1991) Stimulatory and inhibitory effects of glucose and insulin on rat blastocyst development in vitro. Diabetes 40 641-647

Jansen M, van Schaik FMA, Ricker AT, Bullock B, Woods DE, Gabbay KH, Nussbaum AL, Sussenbach JS and Van den Brande JL (1983) Sequence of cDNA encoding human IGF-I precursor Nature $306609-612$

Kaye PL, Bell KL, Beebe LFS, Dunglison GF, Gardner HG and Harvey MB (1992) Insulin and insulin-like growth factors (IGFs) in preimplantation development Reproduction Fertility and Development 4 373-386

Larson RC, Ignotz GG and Currie WB (1992) Transforming growth factor $\beta$ and basic fibroblast growth factor synergistically promote early bovine embryo development during the fourth cell cycle Molecular Reproduction and Development 33 432-435

Le Roith D, Kavsan VM, Koval AP and Roberts CT (1993) Phylogeny of the insulin-like growth factors (IGFs) and receptors: a molecular approach Molecular Reproduction and Development 4 119-123

Lei ZM and Rao CV (1992) Expression of epidermal growth factor (EGF) receptor and its ligands, EGF and transforming growth factor-alpha, in human Fallopian tubes Endocrinology 131 947-957

Lewis AMcD, Kaye PL, Lising R and Cameron RDA (1992) Stimulation of porcine synthesis and expansion of pig blastocysts by insulin in vitro. Reproduction Fertility and Development 4 119-123

Lighten AD, Hardy K, Winston RML and Moore GE (1997) Expression of mRNA for the insulin-like growth factors and their receptors in human preimplantation embryos Molecular Reproduction and Development 47 134-139

MacDonald RG, Pfeffer SR, Coussens L, Tepper MA, Brocklebank CM, Mole JE, Anderson JK, Chen E, Czech MP and Ulirich A (1988) A single receptor binds insulin-like growth factor II and mannose-6-phosphate Science 239 1134-1137

Madan ML, Singla SK, Chauhan MS and Manik RS (1994) In vitro production and transfer of embryo in buffaloes Theriogenology 28 747-753

Matsui M, Takahashi Y, Hishinuma M and Kanagawa H (1995) Stimulatory effects of insulin on the development of bovine embryos fertilized in vitro. Journal of Veterinary Medical Science 57 331-336

Miller DA, Lee A, Pelton RW, Chen EY, Moses HL and Derynck R (1989) Murine transformin growth factor- $\beta 2$ cDNA sequence and expression in adult tissues and embryos Molecular Endocrinology 3 1108-1114

Morgan DO, Edman JC, Standring DN, Fried VA, Smith MC, Roth RA and Rutter WJ (1987) Insulin-like growth factor II receptor as a multifunctional binding protein Nature 329 301-307

Narula A, Taneja M and Totey SM (1996) Morphological development, cell number, and allocation of cells to trophectoderm and inner cell mass of in vitro fertilized and parthenogenetically developed buffalo embryos: the effect of IGF-I Molecular Reproduction and Development 44 343-351

Palma GA, Muller M and Brem G (1997) Effect of insulin-like growth factor I (IGF-I) at high concentrations on blastocyst development of bovine embryos produced in vitro. Journal of Reproduction and Fertility 110 347-353

Pawshe CH, Appa Rao KBC and Totey SM (1998) Effect of insulin-like growth factor I and its interaction with gonadotropins on in vitro maturation and embryonic development, cell proliferation and biosynthetic activity of cumulus cells and granulosa cells in buffalo Motecular Reproduction and Development 49 277-285

Rappolee DA, Wang A, Mark D and Werb Z (1989) A novel method for studying mRNA phenotypes in single or small numbers of cells Journal of Cellular Biochemistry 39 1-11

Rappolee DA, Sturm KS, Behrendtsen O, Schultz GA, Pedersen RA and Werb Z (1992) Insulin-like growth factor II acts through an endogenous growth pathway regulated by imprinting in early mouse embryos Genes and Development $6939-952$

Sambrook J, Fritsch EF and Maniatis T (1989) Molecular Cloning: A Laboratory Manual 2nd Edn, Cold Spring Harbor Laboratory Press, Cold Spring Harbor, NY

Schultz GA, Hogan A, Watson AJ, Smith RM and Heyner S (1992) Insulin, insulin-like growth factors and glucose transporters: temporal patterns of gene expression in early murine and bovine embryos Reproduction Fertility and Development $4361-371$

Schultz GA and Heyner S (1993a) Growth factor in preimplantation mammalian embryos $O x$ ford Reviews of Reproductive Biology 15 43-81

Schultz GA, Hahnel A, Arcellana PM, Wang L, Goubau S, Watson A and Harvey M (1993b) Expression of IGF ligand and receptor genes during preimplantation mammalian development Molecular Reproduction and Development $35414-420$

Telford NA, Watson AJ and Schultz GA (1990a) Transition from maternal to embryonic control in early mammalian development: a comparison of several species Molecular Reproduction and Development 26 90-100

Telford NA, Hogan A, Franz CR and Schultz GA (1990b) Expression of genes for insulin and insulin-like growth factors and receptors in early postimplantation mouse embryos and embryonal carcinoma cells Molecular Reproduction and Development 26 81-92

Tokunaga K, Taniguchi H, Yoda K, Shimizu M and Sakiyama S (1986) Nucleotide sequence of a full-length cDNA for mouse cytoskeletal b-actin mRNA Nucleic Acids Research 142829

Totey SM, Singh G, Taneja M, Pawshe CH and Talwar GP (1992) In vitro maturation, fertilization and development of follicular oocytes from buffalo (Bubalus bubalis) Journal of Reproduction and Fertility 95 597-607

Totey SM, Pawshe CH and Singh GP (1993a) In vitro maturation and fertilization of buffalo oocytes (Bubalus bubalis): effects of media, hormones and sera Theriogenology 39 115-117

Totey SM, Pawshe CH and Singh GP (1993b) Effect of bull heparin and sperm concentration in in vitro fertilization of buffalo (Bubalus bubalis) oocytes matured in vitro. Theriogenology 39 887-898

Totey SM, Daliri M, Appa Rao KBC, Pawshe CH, Taneja M and Chillar RS (1996a) Differential cleavage and development rates and their correlation with cell numbers and sex ratios of buffalo embryos generated in vitro. Theriogenology 45 521-533

Totey SM, Pawshe CH and Appa Rao KBC (1996b) In vitro maturation of buffalo oocytes: role of insulin and its interaction with gonadotrophins Journal of Reproduction and Fertility Supplement 50 113-119

Ullrich A, Bell JR, Chen EY et al. (1985) Human insulin receptor and its relationship to the tyrosine kinase family of oncogenes Nature 313 756-761

Ullich A, Gray A, Tam A et al. (1986) Insulin-like growth factor I receptor primary structure; comparison with insulin receptor suggests structural determinants that define functional specificity EMBO Journal 5 2503-2512

Viuff D, Hyttel P, Greve T, Eriksen T and Alexandersen S (1995) Transcription and localization of growth factor mRNA in the bovine oviduct Molecular Reproduction and Development 42 28-34

Watson AJ, Hogan A, Hahnel A, Wiemer KE and Schultz GA (1992) Expression of growth factor ligand and receptor genes in the preimplantation bovine embryo Molecular Reproduction and Development 31 $87-95$

Zhang X, Kidder GM, Watson AJ, Schultz GA and Armstrong DT (1994) Possible roles of insulin and insulin-like growth factors in rat preimplantation development: investigation of gene expression by reverse transcription-polymerase chain reaction Journal of Reproduction and Fertility $100375-380$ 